\title{
Between Utility and Right: Where to Meet Animals?
}

\section{Yarar ile Hak Arasında: Hayvanlarla Nerede Buluşmalı?}

\author{
Özgür Aktok ${ }^{1}$
}

${ }^{1}$ (Dr. Öğr. Üyesi), İzmir Kâtip Çelebi Üniversitesi, Sosyal ve Beşerî Bilimler Fakültesi, Felsefe Bölümü, İzmir, Türkiye

\section{ORCID: Ö.A. 0000-0003-3730-334X}

\section{Corresponding author/Sorumlu yazar:} Özgür Aktok

İzmir Kâtip Çelebi Üniversitesi, Sosyal ve Beşerî Bilimler Fakültesi, Felsefe Bölümü, İzmir, Türkiye

E-mail/E-posta: ozgur.aktok@ikc.edu.tr

Submitted/Başvuru: 27.05.2021

Revision Requested/Revizyon Talebi: 16.06.2021

Last Revision Received/Son Revizyon: 18.06.2021

Accepted/Kabul: 19.06.2021

Citation/Atıf: Aktok, Ozgur. "Between Utility and Right: Where to Meet Animals?" Felsefe Arkivi-Archives of Philosophy, 54 (2021): $29-47$. https://doi.org/10.26650/arcp.943883

\section{ABSTRACT}

As members of the most evolutionarily developed species on earth, most of us share the common-sensical belief that our treatment of animals should be based more or less on moral grounds. However, it is also an undeniable fact that for more than two millennia, from the appearance of the first moral theories in Ancient Greece until almost the last quarter of the $20^{\text {th }}$ century, this traditional moral concern for animals has gone hand in hand with their systematic exclusion from the moral community of human beings, which deprives them of basic protective rights against moral abuse and mistreatment. A radical paradigm shift in ethics emerges, especially in the last quarter of the 20th century, when some philosophers begin to question this anthropocentric conception of ethics and the "otherness" of animals in terms of their traditional location outside the ethical discourse. Peter Singer, who is a utilitarian, and Tom Regan, who defends the "rights view" against Singer's utilitarianism, are two prominent representatives of this new ethical approach. After showing how Singer and Regan reject speciesism, this paper focuses on Regan's critique of Singer's account and adds new objections that show that utilitarianism has serious general defects even if it is restricted to human beings. Moreover, these defects give rise to more complicated problems when utilitarianism is applied to animals. After pointing to some weak aspects in Regan's theory, the paper spells out the sketch of an alternative account that points to the possibility of a synthesis of utility principle and right principle. Accordingly, Regan's worse-off principle deduced from the rights view is interpreted as a formal principle, while the utility principle as the material content of it is accepted: as long as there is no violation of the worse-off principle, one ought to deduce particular commands to maximize utility for specific cases out of the application of the utility principle. In this context, the worse-off principle has only a negative and formal function that prevents the utility principle from overriding individual rights by giving it its obligatory form..

Keywords: Applied Ethics, Animal Morality, Speciesism, Utilitarianism, Rights View

\section{Öz}

Evrimin yeryüzündeki en gelişmiş türünün üyeleri olarak, hayvanlara davranma biçimimizin az ya da çok ahlaki temellere dayanması gerektiği yönündeki sağ duyusal görüşte çoğumuz uzlaşırı. Ancak ilk etik teorilerin Antik Yunan felsefesinde ortaya 
çıkmasından yirminci yüz yılın neredeyse son çeyreğine kadar süren iki bin yılı aşkın süre boyunca, hayvanlara yönelik bu geleneksel ahlaki ilginin, bir yandan da onların insanlar-arası ahlak topluluğundan dışlandığı ve bu nedenle temel hakların koruyuculuğundan mahrum kalarak ahlaki bakımdan istismar edildikleri bir yaklaşımla iç içe geçerek günümüze kadar ulaşmış olduğu inkar edilemez bir gerçektir. Yirminci yüzyılın özellikle son çeyreğine girerken, bazı filozofların bu insanmerkezci etik anlayışını ve hayvanların etik söylem alanının dışındaki konumlandırılışlarını sorgulamaya başlamalarıyla birlikte, etikte radikal bir paradigma değişimi ortaya çıkar. Yararcılığı savunan Peter Singer ve buna karşı haklar-görüşünü öne süren Tom Regan, hayvanları da içeren, daha kapsayıcı bu yeni etik yaklaşımın önde gelen iki temsilcisi olarak belirir. Bu makale, ilk olarak Singer ve Regan'ın türcülüğü nasıl reddettiklerini gösterdikten sonra, Regan'ın Singer eleştirisine odaklanarak bu eleştiriyi yeni itirazlar ile geliştirmektedir. Bu itirazlar, yararcılığın yalnızca insanlara sınıllandıııldığı zaman bile ciddi sorunlarla karşılaştığı ve hayvanları da içerecek şekilde uygulandığında daha da karmaşık problemlere neden olduğunu göstermektedir. Makale bu bağlamda Regan'ın teorisindeki bazı zayıf noktalara temas ettikten sonra, en sonunda yararcılık ile haklar-görüşünün bir sentezinin olanağına işaret eden alternatif bir yaklaşımın taslağını öne sürmektedir. Bu alternatif yaklaşım, Regan'ın haklargörüşünden çıkarsadığı "daha-kötü-olma” ilkesini (the worse-off principle) formel bir ilke olarak kabul ederken, Singer'ın yarar ilkesini bu formel ilkenin materyal içeriği olarak yorumlamaktadır: "Daha-kötü-olma" ilkesi çiğnenmediği sürece, yarar ilkesinin uygulanmasından ahlaki durumlara yönelik tikel buyruklar yarar maksimize edilecek şekilde türetilmelidir. Bu bağlamda, "daha kötü olma" ilkesinin, yalnızca yarar ilkesinin bireysel hakları ç̧ğnemesini önleyen negatif ve formel bir işlevi vardır ve bu ilke, kendi işlevini, yarar ilkesinin bireysel hakları çiğnemesini ona yükümlülük formunu sağlamak yoluyla önleyerek gerçekleştirir. Keywords: Uygulamalı Etik, Hayvan Ahlakı, Türcülük, Yararcılık, Haklar Görüşü

\section{Introduction: Speciesism as Irrational Exclusion of Animals from Moral Community}

The ethical view that only human beings are worthy of moral consideration is called "speciesism." In 1970, Richard Ryder coined this term by pointing to the fact that "since Darwin, scientists have agreed that there is no 'magical' essential difference between human beings and other animals, biologically-speaking. Why then do we make an almost total distinction morally? If all organisms are on one physical continuum, then we should also be on the same moral continuum." Basing his definition of speciesism on this insight, Ryder concludes that the view defending such an essential difference is “just 'speciesism,' and as such, it is a selfish emotional argument rather than a reasoned one." In another paper, Ryder uses the term again in comparison to "racism" to show their similarity:

In as much as both "race" and "species" are vague terms used in the classification of living creatures according, largely, to physical appearance, an analogy can be made between them. Discrimination on grounds of race, although most universally condoned two centuries ago, is now widely condemned. Similarly, it may come to pass that enlightened minds may one day abhor "speciesism" as much as they now detest "racism." The illogicality in both forms of prejudice is of an identical sort. If it is accepted as morally wrong to deliberately inflict suffering upon innocent human creatures, then it is only logical to also regard it as wrong to inflict suffering on innocent individuals of other species. ... The time has come to act upon this logic. $^{2}$

1 Richard D Ryder, "Speciesism Again: the original leaflet", in Critical Society 2 (2010 Spring): 1-2. Erişim 7 Mayıs 2021.

2 Richard D Ryder, Animals, Men and Morals, ed. Stanley, Roslind Godlovitch, John Harris (London: Victor Gollancz, 1971), 81. 
While Ryder's coinage and introduction of the term "speciesism" is followed by a multiple number of works ${ }^{3}$ popularizing it further, it is especially Peter Singer's philosophical contribution to it in his path-breaking work Animal Liberation that brings it to a peak level of maturity. Singer makes speciesism into a basic concept in the study of contemporary ethics, which shifts the focus from man to animals and tries to formulate a more inclusive, unitary moral theory than the traditional ones, applicable not only to human beings, but also to animals. Like Ryder, Singer underlines the pattern similarity of speciesism to racism:

The racist violates the principle of equality by giving greater weight to the interests of members of his own race, when there is a clash between their interests and the interests of those of another race. Similarly the speciesist allows the interests of his own species to override the greater interests of members of other species. The pattern is the same in each case. ${ }^{4}$

If we focus on Singer's further definition of speciesism as "a prejudice or attitude of bias in favor of the interests of members of one's own species and against those of members of other species," and look at speciesism within its two basic functions of "inclusion" and "exclusion," it can be characterized as an unjustified exclusion of animals by human species from moral community. The ethically undesirable consequence of speciesism is not difficult to establish: Since the exclusion of animals means that they are not equal with us, homo sapiens, they are kept out of the range of the protective power of the ethical principle of equality. This deprivation results in a systematic abuse and mistreatment of animals in various ways: factory farming, animal slaughter, blood sports, taking of their fur and skin, etc.

It is an important question how fruitful Singer's and Regan's critiques of speciesism have been with respect to the consistency of their expansion of ethics beyond the traditional humancentered morality if we take into consideration that their basic concern seems to be restricted to animals rather than the whole ecological system of our planet. There have been serious objections to both philosophers, which proclaim that even though their ethical theories take into consideration a considerable number of animals, this seeming expansion of the range of ethical discourse fails to overcome the anthropomorphic conception of morality. It is argued that, in this way, despite their critique of traditional ethics as a form of speciesism, Singer and Regan fall prey to a new hierarchy between members of moral community because their views are somehow still conditioned and limited by the traditional anthropomorphic conceptual tools and ways of making sense of animal morality. Environmental ethics as a critical response to this allegedly

3 Two examples to consider how the term is used in a larger and comperative context: Andrew Oberg, "All too human? Speciesism, racism, and sexism", Think 15 (2016), 43. Erişim 10 Mayıs 2021. URL: https://www.cambridge.org/core/journals/think/article/abs/all-too-human-speciesism-racism-and sexism/71147DF4646FC4F68601FB61C949E4E1 ve Simon Cushing, "Against "Humanism": Speciesism, Personhood, and Preference”, Journal of Social Philosophy 34 (2003 October): 556-57. Erişim 10 May1s 2021. URL: https://onlinelibrary.wiley.com/doi/abs/10.1111/1467-9833.00201

4 Peter Singer, Animal Liberation $2^{\text {nd }}$ Ed (London: Jonathan Cape, 1990), 6.

5 Peter Singer, Animal Liberation, 5-6. 
anthropomorphic conception of animal ethics seems to demand to include more radically as much components of our ecological unity as possible no matter whether they are animals or not (ecological components like microorganisms, more primitive animals, plants, inorganic natural beings like mountains, rivers, etc.). These radical critiques of anthropomorphism ${ }^{6}$ resulting from environmental ethical approaches remain beyond the scope of this paper because it aims to solve certain specific problems within the sphere of animal morality concerning animal rights and liberation as is problematized by Singer and Regan. It is another important task to discuss how to respond to these critiques in the larger context of the debates over environmental philosophy. However, since these critiques are not directly relevant to the basic argument this paper aims to develop, they are put aside for now to be worked out in a separate writing.

In the following sections, first I aim to show how Regan and Singer reject speciesism. Second, I present Regan's critique of Singer's theory while adding my own objections that show that utilitarianism is a flawed doctrine in general, even if it applies only to the human species. Moreover, these flaws give rise to more complicated problems when utilitarianism is expanded to include animals, as Singer attempts to do. After pointing to some weak aspects in Regan's theory, I elucidate the sketch of an alternative account that points to the possibility of a synthesis of the utility principle and the right principle. In this context, as I will try to show in the last section, in this alternative possible account, Regan's worse-off principle (derived from the right principle) has only a negative and formal function that prevents Singer's utility principle from overriding individual rights by giving it its obligatory form.

\section{Singer's Critique of Speciesism}

Singer tries to show that the universal "no harm" principle of utilitarianism actually covers animals if we interpret it as a principle which attempts to reduce suffering for all living beings, including human beings. If we examine animals empirically without speciesist bias, it is not hard to detect that they can suffer just like human beings. Speciesism results partly from the ignorance of this fact and the presupposition that animals lack the capacity for suffering. ${ }^{7}$ Singer mentions good empirical reasons that undermine these traditional ideas based on speciesism. This ignorance about animals and their suffering leads to an inconsistent application of the universal principle of utility. In Chapter 1 of Animal Liberation, Singer also presents a critique of the traditional conception of equality that excludes animals from the range of the application of the utility principle. In the traditional picture, equality should be granted to those which have greater

6 As examples of this kind of critiques see Holmes Rolston, A New Environmental Ethics: The Next Millennium for Life on Earth, New York: Routledge, 2012. J. Baird Callicot "Non-Anthropocentric Value Theory and Environmental Ethics", American Philosophical Quarterly, 21(4)/2012: 299-309. For a general presentation of such critiques also see Haluk Aşar, "Hayvan Haklarına Yönelik Temel Görüşler ve Yanılgıları” in Kaygı. Bursa Uludăg Üniversitesi FenEdebiyat Fakültesi Felsefe Dergisi (30) (2018), 239-251.

7 One such example of negligence or ignorance is Descartes's conception of animals as automata. Despite the empirical appearance that animals suffer when exposed to pain-producing stimulus, he insists on his conviction that this is only a misleading illusion at the observational level and animals actually do not feel pain at all because unlike human beings, they lack soul. According to Descartes, animals belong purely to the realm of the physical universe governed by mechanical laws of nature. 
capacities. Since human beings constitute the species with greater capacities on earth, animals are kept out of the discourse of equality by being excluded from the realm of possible beings that deserve equality. Traditional conception seems to see equality as an "internal" criterion among the members of an enclosed group of beings. As Singer claims, however, instead of rejecting the difference and trying to force beings to fit our traditional and anthropomorphic definition of equality, we can try to reinterpret it such that it embraces the plurality, diversity, and richness of living beings. In this case, animals, too, fit our new definition. Since the traditional conception puts beings into a hierarchical structure on the basis of their moral capacity, intelligence, physical strength, etc., Singer refuses to consider such capacities as requirements for equality. However, giving up these capacity requirements does not necessarily mean a rejection of the "capacity requirement" completely. He rather minimalizes the requirements and offers one simple criterion: the capacity for suffering. Consequently, Singer's utilitarian solution to the problem is to increase total enjoyment and to decrease total suffering for all living beings, including animals. The virtue of Singer's work seems to be its insight into the problems of the traditional conception. He questions the current definition of eligibility to be equal, and offers a new definition, which can cover the diversity and richness of living beings. ${ }^{8}$

\section{Regan's Critique of Speciesism}

Basing his ethical views concerning animals on Kantian legacy, Regan rejects utilitarianism as a form of consequentialism, and develops a deontological approach upon the key concept of "right." According to the deontological approach, the rightness or wrongness of a moral action does not result from its consequence; it is rather determined by the respect for the inherent value of the individual who is affected by that action. Accordingly, we cannot treat another individual merely as a means to an end and have the duty to respect him/her as a person no matter whether our treatment increases or decreases the total amount of utility for the greatest number. To act on the basis of utilitarian principle is nothing but taking an individual to be an instrument and seeing him/her as having an instrumental value in reaching the goal of utility. Such attribution of instrumental value to human beings is categorically rejected by Kant's as well as Regan's ethics of obligation. However, despite this Kantian framework of his position, Regan diverges from it partly by rejecting its basic assumption that morality should be based strictly on universal rationality exceptionally found in human reason. Instead of "being rational," Regan proposes the criterion of "being subject-of-a-life" to characterize the eligibility for being a member of a moral community. Accordingly, Regan's key concept of being subject-of-a-life

involves more than merely being alive and more than merely being conscious. ... individuals are subjects-of-a-life if they have beliefs and desires; perception, memory, and a sense of the future, including their own future; an emotional life together with feelings of pleasure and pain; preference- and welfare-interests; the ability to initiate action in pursuit of their desires and goals; a psychophysical identity over time; and an individual welfare in the sense that their experiential life fares well or ill for them, logically independently of their utility for others and 
logically independently of their being the object of anyone else's interests. Those who satisfy the subject-of-a-life criterion themselves have a distinctive kind of value - inherent value - and are not to be viewed or treated as mere receptacles. ${ }^{9}$

As can be seen, "being subject-of-a-life" is a much broader concept than "being rational" because the latter covers a considerable number of animals, even if not all of them. In the light of this new criterion then, animals, too, have rights and as human species, we are not allowed to abuse them in favor of our interests. In this way, Regan believes he has shown the inconsistency of the traditional conception of morality by looking for empirical evidence pointing to the fact that many animals can actually be seen as individuals who are subjects of a life just like human beings. Clearly, Regan's "being subject-of-a-life" criterion is richer than Singer's minimalist criterion of "being capable of suffering." It means having a psycho-physical identity over time involving skills like having beliefs, desires, memory, perception, intention, self-consciousness, and a sense of future.

From the respect principle concerning subjects-of-a-life, Regan deduces the "no harm" principle, which is non-utilitarian. In his paper "Rights, Justice, and Duties to Provide Assistance: A Critique of Regan's Theory of Rights," Dale Jamieson summarizes perfectly how Regan bases the respect principle on the postulate of inherent value, and then how he deduces the no harm principle from the respect principle while showing in which way this deduction is related to the ethically non-utilitarian concept of justice:

Regan argues in the following way. Everything with inherent value must have equal inherent value, since the alternative would lead to a "perfectionist" theory of justice, one which sanctions differential treatment of individuals on the basis of the degree to which they exemplify various virtues. According to Regan, perfectionist theories of justice have morally pernicious consequences and, hence, are unacceptable. Since both moral agents and "patients"-those individuals, like infants and most animals, who can be benefited or harmed but are not responsible for their actionsare "subjects of a life," they are of equal inherent value. Next Regan introduces the Respect Principle, which "rests on" the Postulate of Inherent Value. It states that we must treat those individuals who have inherent value in ways that respect their inherent value. According to Regan, the Respect Principle requires not only that we refrain from treating others in ways forbidden by this principle but also that we come to their defense when they are threatened by moral agents. Regan takes the Respect Principle to imply the Harm Principle. This principle tells us that we must not harm either moral agents or patients, since to harm them is to treat them in ways which do not respect their inherent value. Regan goes on to argue that these principles generate basic rights: creatures who have inherent value have basic rights. It is not merely that it would be wrong for us to treat others in ways that are forbidden by these principles but, rather, that to do so would be unjust. ${ }^{10}$

9 Tom Regan, The Case for Animal Rights, (University of California Press, 1983), 243.

10 Dale Jamieson, “Rights, Justice, and Duties to Provide Assistance: A Critique of Regan's Theory of Rights”, Ethics 2 (1990), 350. 
So, the crucial difference between Singer and Regan is that Regan attaches an equal inherent value to each particular member of the moral community, and as a result, he also attaches the right not to be harmed by others. The difference of this principle from the utilitarian "no harm" principle is that the latter does not attach an inherent value to animals and human beings themselves, but an intrinsic value to the calculable utility outcomes they can produce. This difference also constitutes the heart of Regan's objection to Singer's utilitarianism for its conception of moral agents as mere "receptacles" of values which lack inherent value.

\section{Regan's Critique of Singer's Utilitarianism}

At first sight, we cannot find any apparent weakness in Singer's account with respect to its success in dealing with speciesism. Actually, Singer's criterion of "being capable of suffering" is even more minimalistic and simple, and therefore more inclusive than Regan's relatively complex criterion of "being subject-of-a-life." If this is the case, then how can we make sense of the fact that Regan constructs his whole ethics upon a harsh critique of Singer's utilitarianism? The answer is not difficult to find: although being "anti-speciesist" is a necessary condition for being a good ethical theory concerning animals, it is not sufficient and does not automatically guarantee that an ethical theory does not have more general and serious problems. Actually, this is exactly the way Regan argues against Singer: as Regan tries to show, problems arise within a utilitarian framework because utilitarianism is a flawed doctrine in general, regardless of its rejection of speciesism, and it fails to give a plausible account if applied to animals in particular. That is why, in the rest of this paper, I won't restrict the scope of discussion particularly to animal morality, but focus on more general aspects of Singer's utilitarianism and Regan's rights view, before I come back to theoretical issues concerning particular situations involving animals.

As Jamieson correctly notes, Regan starts his argumentation against Singer with a standard and traditional critique of utilitarianism:
A familiar objection to utilitarianism is this: utilitarianism regards individuals as valuable only insofar as they contribute to making the world a better place; when individuals cease to so contribute, either by being unhappy themselves or by causing others misery, it is not wrong to kill them. But this conclusion is unacceptable. Regan's positive theory begins from this familiar objection. He charges that utilitarianism views individuals as "mere receptacles" for value ${ }^{11}$

Regan's critique can be summarized as follows: Utilitarianism is an aggregative theory that makes calculations about the utility of keeping human beings alive, yet it ends up missing the crucial point that it is individuals themselves who should be valued in the first place. However, they are treated as "mere receptacles" for value. If utility is taken as the only and primary criterion, then utilitarian calculations lead to some hypothetical cases in which the maximization criterion is achieved but morally unacceptable actions take place, like victimizing someone or a minor group for the greater utility of majority. Regan expresses this problem in one of his counterexamples perfectly:

11 Jamieson, "Rights, Justice, and Duties to Provide Assistance: A Critique of Regan's Theory of Rights", 349-350. 
That utilitarianism is an aggregative theory -different individuals' satisfactions or frustrations are added, or summed, or totalled- is the key objection to this theory. My Aunt Bea is old, inactive, a cranky, sour person, though not physically ill. She prefers to go on living. She is also rather rich. I could make a fortune if I could get my hands on her money, money she intends to give me in any event, after she dies, but which she refuses to give me now. In order to avoid a huge tax bite, I plan to donate a handsome sum of my profits to a local children's hospital. Many, many children will benefit from my generosity, and much joy will be brought to their parents, relatives, and friends. If I don't get the money rather soon, all these ambitions will come to naught. The once-in-a-lifetime opportunity to make a real killing will be gone. Why, then, not kill my Aunt Bea? Oh, of course I might get caught. But I'm no fool and, besides, her doctor can be counted on to cooperate (he has an eye for the same investment and I happen to know a good deal about his shady past). The deed can be done ... professionally, shall we say. There is very little chance of getting caught. And as for my conscience being guiltridden, I am a resourceful sort of fellow and will take more than sufficient comfort -as I lie on the beach at Acapulco- in contemplating the joy and health I have brought to so many others. Suppose Aunt Bea is killed and the rest of the story comes out as told. Would I have done anything wrong? Anything immoral? One would have thought that I had. Not according to utilitarianism. Since what I have done has brought about the best balance between totalled satisfaction and frustration for all those affected by the outcome, my action is not wrong. Indeed, in killing Aunt Bea the physician and I did what duty required. This same kind of argument can be repeated in all sorts of cases, illustrating, time after time, how the utilitarian's position leads to results that impartial people find morally callous. It is wrong to kill my Aunt Bea in the name of bringing about the best results for others. A good end does not justify an evil means. Any adequate moral theory will have to explain why this is so. Utilitarianism fails in this respect and so cannot be the theory we seek. ${ }^{12}$

Regan's "murder of the aunt" example above typically lets us realize something intuitively wrong in this scenario because, despite the maximization of utility, the murder of an innocent person disturbs us deeply: "Poor Aunt Bea does not deserve to be killed," we say. Regan's critique is that the utility maximization for the greatest number sometimes leads to a violation of the respect principle. We can find many similar examples indicating that the utility principle is satisfied even though someone is murdered or severely harmed, and this seems to be ethically unacceptable. Another typical example of this sort was already given by Mc Closkey at the end of 1950's:

12 Tom Regan, "A Case for Animal Rights" in Advances in Animal Welfare Science Ed. M.W. Fox \& L.D. Mickley (Washington, DC: The Humane Society of the United States, 1986), 185-186. 
Suppose that a sheriff were faced with the choice either of framing a Negro for a rape that had aroused hostility to the Negroes (a particular Negro generally being believed to be guilty but whom the sheriff knows not to be guilty) —and thus preventing serious anti-Negro riots which would probably lead to some loss of life and increased hatred of each other by whites and Negroes_ or of hunting for the guilty person and thereby allowing the anti-Negro riots to occur, while doing the best he can to combat them. In such a case the sheriff, if he were an extreme utilitarian, would appear to be committed to framing the Negro. ${ }^{13}$

In the Sheriff scenario, framing the Negro, which maximizes utility at the cost of being unjust to him, appears to be an ethically unacceptable outcome. Note that the term "extreme utilitarianism" in the example is used as the older version of the term "act utilitarianism," which is distinguished from "rule utilitarianism" in contemporary ethics. In the 1950's, extreme utilitarianism, as opposed to restricted utilitarianism, was used in the sense of the classical utilitarian approach as found in Jeremy Bentham's ethics that attempts to justify each action directly on the basis of utility calculation. However, since this kind of a justification requires an impractical method (each time and for each action, one has to make calculations and make a decision on that particular evaluation, and this does not work efficiently given the complexity of many situations and the subjective epistemic limitations which easily result in misjudgments in the long term), some advocates of utilitarianism develop a more complex form of utilitarianism which tries to justify an action on the basis of long-term rules rather than immediate particular acts. This rule-based utilitarianism is called "restricted utilitarianism" because it does not base its justification on the immediacy of particular actions and can avoid utility maximization in the short term. Extreme utilitarianism seems to be concerned with an immediate set of actions and short-term outcomes, and that is why it is called "extreme." On the other hand, "restricted utilitarianism" might prevent one from applying the maximization of utility principle in the short term without taking into consideration the long-term negative outcomes, since the longterm negative outcomes might overweigh the short-term positive gains. ${ }^{14}$ However, this classical terminology is replaced later by the act- vs. rule-utilitarianism distinction, especially with the rise of rule-oriented utilitarianism in the second half of the $20^{\text {th }}$ century. ${ }^{15}$ Hare argues that rule utilitarianism collapses into act utilitarianism and there is no essential difference between the two versions except that the latter is a more generalized version of the former. ${ }^{16}$

13 H. J. McCloskey, "An Examination of Restricted Utilitarianism” in Philosophical Review 66 (1957 October): 466485.

14 Extreme vs. restricted utilitarianism as terminology can be found in Smart, J. J. C. Smart, "Extreme and Restricted Utilitarianism”, Philosophical Quarterly 6 (1956): 344-354. and McCloskey, "An Examination of Restricted Utilitarianism", 466-485.

15 Urmson's interpretation of Mill's utilitarianism as a form of rule-oriented utilitarianism plays a crucial role in the emergence of this new approach and terminology. See J. O. Urmson, "The Interpretation of the Moral Philosophy of J. S. Mill”, Philosophical Quarterly 3 (1953): 33-39.

16 M. Hare, “The Presidential Address: Principles" in Proceedings of the Aristotelian Society 73:(1972-1973): 1-18. 
Regan distinguishes between two sorts of utilitarianism: Hedonistic utilitarianism and preference utilitarianism. The latter is Singer's position, as Singer himself explicitly defines his position as preference utilitarianism. Unlike hedonistic utilitarianism, according to which right actions are determined as those that maximize pleasure, preference utilitarianism proposes to promote actions that fulfil the interests of those beings involved. ${ }^{17}$ Regan's distinction, which is already formulated by Singer himself, however, does not play a crucial role in his criticism of Singer's position because he argues against Singer on the ground of a more general problem intrinsic to all forms of utilitarianism. As Regan declares, utilitarianism in general "provides no basis for the rights of animals and instead contains within itself the grounds for perpetuating the very speciesist practices it was supposed to overthrow." ${ }^{18}$ For example, considering animal experimentation, "for the utilitarian, whether the harm done to animals in pursuit of scientific ends is justified depends on the balance of the aggregated consequences for all those affected by the outcome.' ${ }^{19}$

As can be seen, Regan's objection to Singer's utilitarianism shows us general defects in the theory regardless of its variations. That is why, as Regan's example of the "killed aunt" shows, in many hypothetical utilitarian scenarios, the sum of trivial interests of a big group outweighs and violates the most fundamental, crucial interests and rights of one individual or small group, and this is a serious problem for utilitarianism. This violation might take worse forms like killing an individual or a group of people because it serves greater utility.

\section{Further Objections to Utilitarianism}

A common utilitarian reply to such examples could be that these examples describe unusual, extreme situations, which we normally do not face, and even if we faced them, then the public knowledge of such cases would be expected to lead to a great psychological harm in the long term. The anxiety and feeling of insecurity of each individual that such victimization can happen to him/her or his/her own relatives automatically results in the long term in a minimization of utility rather than maximization. The utilitarian, therefore, concludes that in the long term, such situations are expected to disappear because maximization of utility would necessitate not victimizing the minority. I will show that the following counter-examples reject this defense.

Consider a society consisting of people, the majority of whom have the psychological disorder of sadism. They have a tendency to get considerable pleasure and excitement from victimization. There is nothing wrong in thinking of such a possible scenario in which most of the people have a certain permanent psychological character, even if it can be categorized as "pathological." The majority is motivated for such a controlled and limited victimization. According to the utilitarian,

17 See Peter Singer, Practical Ethics (Cambridge University Press, 2011), 13. Susan Krantz argues against this version of utilitarianism as a version of subjective preferentialism because in Singer's approach, what is right and wrong is based on individual preferences (interests) and there is nothing that is in itself good or bad. See Susan F. Krantz, Refuting Peter Singer's Ethical Theory: The Importance of Human Dignity (Westport: Greenwood Publishing Group, 2002), 28-29.

18 Regan, The Case for Animal Rights, 315.

19 Regan, The Case for Animal Rights, 392. 
in such a society, such victimizations turn out to be ethically right because they contributes to greater utility. For example, if the total sum of pleasure of 1000 unvictimized people is 1000 units, assuming that each individual gets 1 unit pleasure from the pain of the victimized minority, and if the total sum of pain of 10 people is 990, assuming that each victimized individual suffers 99 units of pain, the total sum of pleasure outweighs the total sum of pain. However, it seems obvious that merely the empirical/psychological fact about the members of a society consisting of sadists cannot make an act or a situation morally right or wrong; if such victimizations are wrong, then their wrongness should result from certain moral criteria, which cannot be made contingent and dependent upon the psychological situation of the members of a society.

Now consider a second scenario: you are a utilitarian living in a country in which the government kills the richest people and uses their money for the poor and sick people, and it saves thousands of lives by doing that. This government has a peculiar "Robin Hood" ideology that consists in "taking from the rich and giving to the poor." These victimizations are organized in such a professional way that the deaths of the victims seem completely natural and there is a law which enables the state to take the victims' possessions and money to use it for public good. One day, you accidentally come to know this fact. At that particular time then, you should find such victimizations right because they maximize the overall utility. Suppose the government falls from power after some time, and the strange secret ideology of the state as well as the terrible murders are revealed to the public. Consequently, people fear and get enough psychological harm to such a level that stopping such victimizations turns out to produce maximum utility. As a utilitarian, then, at the time you come to know this new piece of information, you have to change your mind and condemn the victimizations for being morally wrong. There is nothing different with the victimizations themselves, the murders; they are one and the same, but as a utilitarian, you have to change your mind just because of the contingent fact that people now get psychological harm because of the contingent disclosure of a secret of the previous government. This example shows that basing the rightness or wrongness of actions on the accidental appearance or disappearance of side effects - namely, the anxiety that is caused - indicates a serious problem with the utilitarian ethical decision-making process.

Moreover, is there not something ethically disturbing and embarrassing in rendering the criterion for finding an action right or wrong on such negative motivations as "fear" or "anxiety" for oneself and one's own relatives? It seems that there is a sense in which people in an ethically ideal society have the capacity to recognize the rightness or wrongness of actions independently of being threatened and frightened of "what will happen to them in future." The ethical process of finding the victimizations wrong in a utilitarian scenario seems too inefficient to produce proper ethical responses when faced with situations that require immediate action: First we have to wait until a sufficient number of the "survivors" have a sufficient amount of anxiety, and then make calculations. It turns out that only if these victimizations cause less utility than the case in which they are stopped, are we allowed to find those actions wrong. If you are a utilitarian, you are not allowed in the meantime to interfere with those victimizations, and worse, you are expected to find them ethically right. You should simply sit down and sanction all these murders just because there is no sufficient side effect in the society yet, and your calculations do not guide 
you in preventing these murders from taking place. It seems that this utilitarian attitude simply distorts the most crucial characteristic of "ethical action," our sense of responsibility in taking urgent actions when we are faced by sudden ethical problems. It seems that Regan's critique of utilitarianism as a generally flawed doctrine has a point.

The utilitarian might still object in two ways. First, the criticism in these examples seems to be directed at "act utilitarianism" (or hedonist utilitarianism) that focuses on pleasure and pain. Singer's version is preference-utilitarianism. However, this does not affect the existing problem. Susan Krantz rightly argues against Singer's version of utilitarianism as a version of subjective preferentialism because in Singer's account, what is right and wrong is based on individual preferences (interests) and there is nothing that is in itself good or bad..$^{20}$ Therefore, preference utilitarianism might already take the form of a hedonistic utilitarianism in case a community defines "interest" as "pleasure," or even as "pleasure gotten from the pain of others" (sadism). We cannot even question or criticize the interests of the sadist community in the first example or the interests of the "Robin Hood" government in the second example on the basis of an objective/ universal criterion. What they choose to maximize as their utility depends on how they "prefer" to define what "utility" is for them. So, the objection at hand fails.

Second, the utilitarian can point to "rule-utilitarianism" as an alternative to "act-utilitarianism" and "preference-utilitarianism," insisting that rule-utilitarianism might provide a solution. However, as I have pointed out earlier, Hare justifiably argues that rule utilitarianism collapses into act utilitarianism and there is no essential difference between the two versions except that the latter is a more generalized version of the former. ${ }^{21}$ The same problem would inevitably arise in practice even if one holds rule-utilitarianism to solve the problems arising in the examples above. Thus, different versions of utilitarian solutions to this kind of a problem are condemned to fail.

A third possible way for the utilitarian to reply is to remind us that these examples picture unusual and rare situations. Apart from these exceptional cases, utilitarianism works quiet well. But why should we choose "usual" situations in order to test an account? "Usual" does not necessarily mean "good" for testing, as much as "unusual" does not mean "inappropriate." An account might work quite well in usual examples, whereas it might fail in the unusual ones, and it is the task of a philosopher to detect such failures to criticize an account. As utilitarianism teaches us, it is even better to question our usual, common-sense, and traditional convictions. Then why should we try to find examples, which are "usual," if we question utilitarianism itself?

Finally, let's complicate the situation further and consider an example involving animals. This counter-example will show clearly that utilitarianism is even less successful in dealing with ethical issues related to animals. Suppose that the minority group which is victimized this time consists of animals. Imagine that human beings experiment on animals and because of their experimentation, a considerable number of animals are killed. Yet these experiments by human

20 Krantz, Refuting Peter Singer's Ethical Theory: The Importance of Human Dignity, 28-29.

21 Hare, "The Presidential Address: Principles", 1-18. 
beings on animals increase the overall utility for a very large population of human beings and outweigh the utility that would have been reached had those animals not been killed. In this scenario, the utilitarian assumption that public knowledge about the victimizations would in the long term eventually lead to a minimization of utility and therefore the victimizing action would be stopped in the long term simply does not work. Since human beings in this case would not fear for themselves and their peers, it seems hard for them to experience a sufficient amount of psychological harm to outweigh the overall utility human beings get from abusive animal experimentation. With animals then, the situation is even more complicated if we stick to utilitarianism as the primary ethical theory to solve our moral problems.

The basic problem with utilitarianism in all these examples can be characterized as its failure to grasp the ethical fact that although utility is one of the most basic and important values, it is not the only and exhaustive one. Trying to reduce all values to the value of utility results in situations in which, despite the maximization of utility, there is something ethically wrong going on. What disturbs us with the given examples in which a group of people or animals lose their lives is not solely "our old-fashioned moral convictions," but the fact that an individual himself/herself, or his/her life, is a value regardless of the utility it leads to. This is an inherent value, as Regan rightly points out, and is not reducible to the utility it produces. The sacrifice of this value by utilitarianism disturbs us morally by informing us about the injustice of the situation. The utilitarian does not accuse us of being too conservative and obsessed with our old-fashioned intuitions, when for example, we are morally disturbed by the Jewish Holocaust carried out by the Nazis. We are disturbed by the Holocaust not as a result of making theoretical utility calculations, but by direct exposure to strong emotions. Our condemning the Holocaust as "evil" is a result of these feelings of our common humanity. Even a utilitarian would accept that our moral feelings are not totally irrelevant to the rightness or wrongness of actions, states, and events, and they have at least some cognitive function through which we are informed whether an action is right or wrong. At least, there is an undeniable correlation between our feelings and the moral status of actions if the situation is not too complicated. In every situation, there are two possibilities as to why we are ethically so disturbed: it is either because (1) our moral feelings misinform us and there is actually "nothing" wrong in what we experience, or because (2) our moral feelings reflect a value violation. Now, by ruling out the second possibility dogmatically, and sticking to the utilitarian principle, is it not the utilitarian who holds a conservative attitude? It is perfectly possible that the utility principle is not as exhaustive as the utilitarian presupposes it to be, and that our negative moral feelings might be based on our cognition of the violation of an ethical principle. Now, let's compare: on the one side, there is the immodest assumption of the utilitarian that utility is an absolute value and that its maximization always produces "right" actions and states, and we are expected to disregard our moral feelings in favor of this abstract theoretical assumption. The utilitarian does not provide us with a justification, except from his/her insistence not to give up the principle of utility for the sake of the protection of the consistency of his/her monist value doctrine. On the other side, we have a strong negative moral feeling, which we normally rely upon in daily life in terms of its informative function about the 
moral status of actions and states we experience all the time. Note that this informative function always goes hand in hand with our rational consideration and evaluation. In this case, it does not seem so plausible to disregard our moral feelings altogether in favor of the internal consistency of an ambitious theoretical project.

\section{Conclusion: The Possibility of a Synthesis: Right as the Form of Utility}

As is known, the basic problem with deontological theories is their relative failure to provide empirically concrete criteria in particular situations about how to make a moral decision. "Duty" or "right" as abstract concepts seem to resist empirical quantification. In contrast, the utilitarian notions like utility, pain and pleasure, and interest appear to be more or less empirically calculable characteristics. This provides the attractive strength of utilitarianism in offering solutions for concrete situations. I think that Regan's rights view, too, cannot completely overcome this general problem of classical deontological theories because he does not seem to offer a strong "positive" criterion instead of utility for ethical action. He seems to have only the "no harm" principle, which functions only as a negative, limiting condition. The rights view offers us a perfect model for the prevention of cases of injustice, but they are insufficient in offering us the content for the basic motive of ethical action in a positive manner, such as desire, interest, utility, etc. Another crucial problem with the rights view, as we encounter in Regan's account, seems to be that it implies a stronger kind of "hierarchy" within animals compared to Singer's utilitarianism when he attempts to look at them as individual subjects of a life. Since to be an individual requires certain sophisticated capacities like having beliefs, desires, memory, psychophysical identity over time, etc., more animals remain outside of Regan's moral community since they do not possess those capacities, by which we can call them individuals. Singer's account, however, seems to employ a less hierarchical model, which is minimalist: only suffering matters.

Although utilitarianism seems to have some advantages, which I mentioned, it has its own problem of producing ethically unacceptable consequences, and it fails to respond to the criticisms already pointed out. Because of the weak aspects found in both views, I will offer the possibility of a third way, which can be summarized roughly as a synthesis of the utility principle with the respect principle while retaining their independent status. However, this paper does not aim at a detailed account of this alternative view; it provides rather a sketch to be worked out in another study in detail. This means that what I will present here won't be more than a rough idea pointing to the possibility of an alternative and non-monist conception of value. This alternative account is based upon a questioning of the utilitarian insistence on "utility" as the only value for the sake of which all other values should be seen as instrumental: why should we insist on a monism with respect to the existence of values just for theoretical consistency if we can solve more problems with the acceptance of a multiplicity of values? Do we have to stick to one absolute highest value and reduce all others to this single one? An anti-monist conception of value seems to be more plausible and promising because of the following reasons.

It is one thing to say that utility is an important value on the basis of which we can positively and constructively decide whether an action is right or wrong, and another thing to consider it 
as the only (and hence, absolute) criterion for moral actions. While I accept the former, which appreciates the importance of utility as one of the most crucial ones, I reject the latter, which can be called an "absolutist" and "reductionist" account of value. The rejection of the absolutism of utilitarianism means here to accept utility as a conditional value; a value depending on the satisfaction of a further formal condition, which protects individuals from being victimized in unjust situations resulting from utility maximization. The rejection of reductionism of utilitarianism, on the other hand, means to accept the existence of at least one value other than utility, which is the inherent value of being a subject of life, which cannot be reduced to, and expressed by amounts of utility. This inherent value is there just in virtue of the existence of an individual regardless of what it contributes to the sum of utility. To reject utilitarianism in terms of its absolutist and reductionist form does not necessarily mean to reject utility as such. Unlike Regan's "no harm principle," which remains too minimalist, why can't we pose "utility as much as possible" as a positive and constructive element of an ethical theory without sticking to it as the only value? It is perfectly possible to reject utilitarianism while holding the utility principle as one of the highest material values in an ethical account. In this paper, therefore, I defend the utility principle while limiting its scope of application with the right principle. Accordingly, utility should be maximized as long as there is no violation of the right principle, which expresses the inherent and non-instrumental values of individuals. So, although utility is a value, it is not the only one, and there is at least one more value, which is the value of the individual as the subject of utility.

This non-utilitarian value can be expressed as Regan's “worse-off principle:”

Special considerations aside, when we must decide to override the rights of the many or the rights of the few who are innocent, and when the harm faced by the few would make them worse-off than any of the many would be if any other option were chosen, then we ought to override the rights of the many. ${ }^{22}$

According to this principle, which I take over as "the right principle" from Regan, majority does not always count as the ultimate authority, and we should sometimes limit the "summing up" process when individuals (human beings, animals) are severely harmed just because they accidentally belong to the minority overweighed by the utility of majority. This seems to be a legitimate protection of the minority, and individuals from a complete subordination to majority. Now, let me return to the previous examples in which there are victimizations in a society, which increases overall utility. The ethically disturbing contrast between majority and minority is much more present in these counter-examples, in which there is great harm done for the sake of the utility of the majority. The worse-off principle can be applied to all of these extreme examples we have seen. When the worse-off principle is applied to all of these cases, we no longer end up with morally disturbing results: the sadists are not allowed to murder and we are not allowed to experiment on animals.

22 Tom Regan, The Case for Animal Rights (California: University of California Press, 1983. 2004), 305. 
In this context, I interpret Regan's worse-off principle as a formal principle while accepting the utility principle as the material content of this formal principle. Accordingly, the worseoff principle has only a negative function, which prevents the utility principle from overriding individuality. As long as there is no violation of the worse-off principle, we can deduce particular commands for specific cases out of the application of the general utility principle of maximizing utility for the greatest number. That there is no violation of the worse-off principle by the utility principle here means that the empirically expressible utility statements have a conclusive moral validity only if they are in accordance with their form provided by the worse-off principle. Whenever the content turns out to violate this form, it is not a morally valid ethical command even though it maximizes utility. Within the limits of this form, the material content has flexibility: The maximization can be carried out in infinitely many ways and numbers in terms of quality as well as quantity only if it does not violate the obligatory form of the right principle. In this way, the worse-off principle functions as a "safety fuse" or an "inspector" which forms and controls the utility principle. It restricts and determines the ways of maximization by closing off some of its possibilities, which lead to the kind of cases in which the worse-off principle is violated. The crucial difference between Regan's "no harm" principle and the utility principle offered here is that this dual account of values does not try to deduce utility from the right principle, but acknowledges it as a positive and independent value of its own.

While offering a synthesis of utility and right principles, I also want to reply to a possible objection directed to Regan's worse-off principle. Dale Jamieson gives some powerful counterexamples to Regan's worse-off principle, and unless I offer a solution to the problem he points to, my employment of the worse-off principle might remain a doubtful enterprise. Jamieson gives the following counter-examples that point to cases going against our moral intuitions:

Consider two cases. In the first case John is crippled and Mary is not. We must either cripple Mary or cause John a slight headache. The Worse-Off Principle tells us that we must cripple Mary, since John crippled with a headache would be worse off than either John or Mary would be if both were crippled. Consider next a case in which there are a million people who are not crippled and one who is. We must either give the crippled person a headache, or cripple the million. The Worse-Off Principle tells us to cripple the million. ${ }^{23}$

I think that we can interpret Regan's principle in a way which can avoid the problem arising in Jamieson's counter-examples. Consider the first case: Jamieson is right in pointing to the fact that the already crippled John with a headache is worse off than either John or Mary would be if both were crippled. This is fine, but what about the difference between Mary's prior and current state, which is neglected by Jamieson? The not-yet-uncrippled Marry is now crippled and this tragic worsening of Mary's state is incomparably worse than the worsening of the state of John, who gets just a slight headache in addition to his already crippled body. The worse-off principle has to take into consideration not only the final distribution of certain positive or negative

23 Jamieson, "Rights, Justice, and Duties to Provide Assistance: A Critique of Regan's Theory of Rights", 361. 
outcomes, but also the prior states of the agents and how and in which way their prior states worsen in comparison to one another in order to make a healthy decision in the light of the worse-off principle. Thus, I think that it is possible to defend the worse-off principle by comparing John's and Mary's worse-off states and showing that being crippled is much more "worse-off" than getting a headache, and this principle should be applied here in favor of Mary rather than John, although he is crippled plus gets a headache. In Jamieson's examples, that John is already crippled at the prior state is taken into consideration in the calculation of the final outcomes, but the fact that Mary is not yet crippled at the beginning is completely ignored. This seems to be an inconsistent application of the worse-off principle. Therefore, according to this reinterpretation of the worse-off principle, Jamieson's counter-examples fail.

Finally, let me now apply this utility-right synthesis account to a particular case in order to show that it works better than its alternatives and does not lead to the problems encountered in classical counter-examples. Suppose that you are a utilitarian as well as a sensitive person acquainted recently with the animal liberation movement. You learn more about the inhumane conditions in treating animals. Coming to know more details, you start to have a feeling that you are doing something morally wrong by eating meat, and consider the possibility of being a vegetarian. Suppose also that there is a special food which you consume, for which a mammal is killed. Consequently, this food produces a certain amount of utility such as gustatory pleasure for each individual who eats it. However, this food is consumed by such an enormous number of people and exported worldwide that the sum of these small amounts of utility for each individual, i.e. the total aggregate of utility resulting from eating this animal, overweighs the utility resulting from keeping these animals alive. Now, given all these conditions, your utilitarianism is incompatible with being a vegetarian because if you stop eating this food, then this would result in (1) your losing the pleasure of eating that food, which is a utility for you and (2) a decrease in the demand for that food, even though it is small and ignorable, which somehow can create a small negative effect in the overall production and utility maximization process. Whenever the company loses a customer that contributes to this system of utility maximization, the overall efficiency of the system is also harmed slightly. Even though you can ignore (2), there is still (1), which constitutes a strong reason not to give up eating meat. So, utilitarianism has to tell us, for this situation, that there is nothing wrong with your meat consumption. Actually in this picture, it is even morally advisable to go on with it.

Now, this is an example in which utilitarianism produces an ethically undesirable consequence in terms of how we treat animals morally. In contrast to it, the utility-right account I propose would not only allow someone to become vegetarian and stop eating that food, but also impose an obligation upon that person to do so. Since this account consists of a combination of the worse-off principle and the utility principle, and since utility can be maximized only within the limits of the fulfillment of the worse-off principle, one should look first at whether the formal condition is met before examining the content of utility maximization. If we look at the example, we can see that the material principle of utility overrides the formal principle of worse-off. The total sum of utility of a majority, which consists of people worldwide who eat the 
food, overweighs the total sum of utility of a minority, which consists of animals. We cannot compare the utility of a minority directly to the utility of a majority without taking the worse-off principle into consideration. Instead, we should look what utility a particular individual from the majority group gains as a result of giving up the utility of a particular individual from the minority group. Only such a quantitative comparison between "the equal units" of utility, namely, two individuals, can yield us sufficient information about whether there is a violation of the worse-off principle. If you identify yourself as an individual from the majority group, you can see that you have the interest of the taste and the nutritional value of the food, which will be lost if the slaughter of these animals is ended. Nutritional value can easily be compensated through alternative ways of nutrition, so there is no loss for you with respect to it if you stop eating meat. It seems that for you as a particular individual, the only loss is the taste of the food, which gives you a certain amount of pleasure. In contrast to this, if we identify a particular individual animal killed to be eaten by you and compare the harm done to it to the harm you undergo when you give up eating, the harm done to the individual animal appears clearly incomparably high, and thus incomparably unjust: by eating that animal, you kill it in a completely unjust way. The price the eaten animal must pay is too high if it is eaten, in comparison to the price the human individual (which is you in this case) must pay if he/she stops eating it. On the one side, there is the taste of the food as the price to be paid by a human being, on the other side, there is the life of the animal as the price it has to pay. To go on slaughtering means to take the life of the animal away, although it is actually healthy and able to pursue a life of its own. Such a huge inequality of interests harshly violates the worse-off principle, and that is why you ought to renounce your individual right of eating meat. Eating meat violates a right of higher rank, which these animals possess just by virtue of their being animals. This higher rank right is nothing but their right to stay alive and it can override your right to eat meat according to the worse-off principle.

Utilitarianism has always been attractive for its relatively better capacity to offer solutions to concrete situations where we need empirical criteria to make moral decisions. Despite its attraction, however, it also faces many objections due to its compatibility with situations which we reasonably find ethically unacceptable. As I have shown, to condemn all our moral feelings which conflict with utilitarianism simply as common-sense moral convictions in favor of the theoretical consistency of the utilitarian account is groundless because there are good reasons to think that utility is not the only value, though one of the most crucial ones. Moreover, our moral feelings based on non-utilitarian intuitions have some sort of cognitive function that we rely on to a considerable degree. Given all this, it seems plausible to take over the strong aspect of utilitarianism while rejecting its "unintuitive" and "ambitious" part, and combine its commonsense aspect with the rights view. The right principle complements the utility principle at points exactly where the latter comes to its own limit, and fails to cover and explain an ethical situation by the mere principle of utility. Where the principle of utility doesn't work anymore and leads to a morally unacceptable counter-example, as we have seen in many scenarios, the right principle takes hold of the situation. In this way, utility and right are proposed as two complementary values, in whose unity, utility functions as a conditional and material value, the scope of which is limited to the form of rights for all subjects-of-a-life without the slightest discrimination, no matter whether they are human or non-human beings. 
Peer-review: Externally peer-reviewed.

Conflict of Interest: The author has no conflict of interest to declare.

Grant Support: The author declared that this study has received no financial support.

Hakem Değerlendirmesi: Dış bağımsız.

Çıkar Çatışması: Yazar çkar çatış,ması bildirmemiş,tir.

Finansal Destek: Yazar bu çalışma için finansal destek almadığını beyan etmiştir.

\section{References / Kaynaklar}

Aşar, Haluk. "Hayvan Haklarına Yönelik Temel Görüssler ve Yanılgıları" in Kaygı. Bursa Uludağ Üniversitesi Fen-Edebiyat Fakültesi Felsefe Dergisi (30) (2018): 239-251.

Callicot, J. Baird. "Non-Anthropocentric Value Theory and Environmental Ethics", American Philosophical Quarterly, 21(4)/2012: 299-309

Cushing, Simon. “"Against "Humanism": Speciesism, Personhood, and Preference"” in Journal of Social Philosophy 34 (2003 October): 556-571. Erişim 10 Mayıs 2021. URL https://onlinelibrary.wiley.com/ doi/abs/10.1111/1467-9833.00201

Hare, R. M. "The Presidential Address: Principles" in Proceedings of the Aristotelian Society 73 (1972-1973): $1-18$.

Jamieson, Dale. "Rights, Justice, and Duties to Provide Assistance: A Critique of Regan's Theory of Rights" in Ethics 2 (1990): 349-362.

Krantz, Susan F. Refuting Peter Singer's Ethical Theory: The Importance of Human Dignity. Westport: Greenwood Publishing Group, 2002.

McCloskey, H. J. "An Examination of Restricted Utilitarianism" in Philosophical Review 66 (1957 October): 466-485.

Oberg, Andrew. “'All too human? Speciesism, racism, and sexism””. Think 15 (2016): 39-50. E r i ş i m : 10 Mayıs 2021. URL: https://www.cambridge.org/core/journals/think/article/abs/all-too-humanspeciesism-racism-and-sexism/71147DF4646FC4F68601FB61C949E4E1

Regan, Tom. "A Case for Animal Right" in Advances in Animal Welfare Science. M.W. Fox \& L.D. Mickley Ed. Washington, DC: The Humane Society of the United States, 1986/87, 179-189.

Regan, Tom. The Case for Animal Rights. University of California Press, 1983.

Regan, Tom. The Case for Animal Rights. University of California Press, 2004.

Rolston, Holmes. A New Environmental Ethics: The Next Millennium for Life on Earth, New York: Routledge, 2012.

Ryder, Richard D. Animals, Men and Morals, ed. Stanley, Roslind Godlovitch, John Harris, 41-82. London: Victor Gollancz, 1971.

Ryder, Richard D. "Speciesism Again: the Original Leaflet" in Critical Society 2 (2010 Spring): 1-2. Erişim 7 Mayss 2021. https://web.archive.org/web/20121114004403/http://www.criticalsocietyjournal.org.uk/

Archives_files/1.\%20Speciesism\%20Again.pdf

Singer, Peter. Animal Liberation. London: Jonathan Cape, 1990.

Singer, Peter. Practical Ethics. Cambridge: Cambridge University Press, 2011.

Smart, J. J. C. "Extreme and Restricted Utilitarianism”, Philosophical Quarterly 6 (1956): 344-354.

Urmson, J. O. "The Interpretation of the Moral Philosophy of J. S. Mill”. Philosophical Quarterly 3 (1953): 33-39. 
